\title{
The Shaping of Knowledge: Communication of meaning through museum exhibition design
}

\author{
Shamsidar Ahmad'1, Mohamed Yusoff Abbas², \\ Mohd. Zafrullah Mohd. Taib ${ }^{3}$, Mawar Masri ${ }^{1}$ \\ ${ }^{1}$ Post Graduate Studies , 2 Professor, ${ }^{3}$ Senior Lecturer, \\ Faculty of Architecture, Planning \& Surveying, \\ Universiti Teknologi MARA , Malaysia \\ sham68ahmad@yahoo.com.my
}

\begin{abstract}
The primary objective of museum management in shaping of knowledge can be achieved by a communication of meaning through quality displays of the permanent collection or temporary exhibitions, the specimens of a continent or the interactive apparatus of science. This paper looks at research derived primarily from the museum scholars and experts with academics working in the field of visitor studies towards developing exhibits that facilitated visitor learning. These findings are recast the approach in order to offer an integrated framework for visitor behavior has implications for service management of the service encounter at the museum in Malaysia.
\end{abstract}

Keywords: Museum exhibitions design; communication of meaning; shaping of knowledge; quality of life

eISSN 2514-751X @ 2018. The Authors. Published for AMER ABRA cE-Bs by e-International Publishing House, Ltd., UK. This is an open-access article under the CC BY-NC-ND license (http:///creativecommons.org/licenses/by$n c-n d / 4.0)$. Peer-review under responsibility of AMER (Association of Malaysian Environment-Behaviour Researchers), ABRA (Association of Behavioural Researchers on Asians) and CE-Bs (Centre for EnvironmentBehaviour Studies), Faculty of Architecture, Planning \& Surveying, Universiti Teknologi MARA, Malaysia DOI: https://doi.org/10.21834/aje-bs.v3i10.325 


\subsection{Introduction}

Globally, the museum industries have concurred a museum as an organization that a nonprofit making, permanent institution in the service of society. The definition of a museum has evolved, in line with developments in society and in accordance with the realities of the worldwide museum community. The role of museum further as an institution that which acquires, conserves, researches, communicates and exhibits for the purpose of study, educational and enjoyment, material and evidence of people and their environment. These roles of museums are not restricted to just providing information. Today, a visitor may develop such traits as seeing, grasping, analyzing, questioning, extracting clues related to life from what they see (Unal, 2012).

In Malaysia, besides agreeing with International Museum Associations, a museum functions are also a source of knowledge for a holistic view towards all way of life. Ismail (2011) be of opinion that it was seen vital to gather entire material heritage in the construction of cultural identity and the civilization of a country. Museum has also as an institution to spread knowledge to the public on the history, culture and natural history (Tambi, 2011).

This paper intends to initiate a discussion on how museum exhibitions communicates to visitors in delivering information by using those communication media. These findings will be a best-practiced for future exhibition making in helping the shaping of knowledge for Malaysian community.

\subsection{Literature Review}

\subsubsection{Museum Exhibitions as a Function of Museums and the Communication of Meaning}

The exhibitions as a core function of the museums. Museum exhibitions are media of public communication that offer a transformative experience also expanding and altering the visitors awareness, interest and valuation of many aspects of themselves and their world (Lord, 2001). Maryrand (2001), has strongly claimed that the museum exhibition must communicate to the visitors deep to their mind and feeling. The museum has to offer the visitor two things namely:

- collection (objects or archives)

- knowledge (facts or stories)

Those two elements put are together appropriately create "meaning". If this is not accomplished, then the richness of collections and all knowledge in the world will not grow and not appreciated. Meanwhile, Hooper-Greenhill (2000) has viewed that definition of "meaning" in a museum is constructed in relation to the collections, which the museum holds. Objects as collections in museums are assembled to make visual statements, which combined to produce visual narratives. Hence, the ideas that displays have been mounted to communicate in the texts of the exhibition, which may offer a preferred interpretation from 
the various visual elements (display techniques). Previous evident see museum exhibitions primarily as a method of education. The exhibitions succeed if they can educate the visitor about their subject matter and fail if they do not.

Whereas, Dawson (2006) emphasized that museum exhibitions are essentially a medium of communication has led to a new importance placed to promote the visitor experience with contemplative and sophisticated kinds of interactive exhibits with other new means of communicating museum topics. The communication also has conducted with the exhibitions that appeal to the wide variety of learning styles via a mixture of experience types.

\subsubsection{Modes of Exhibitions Apprehension}

The visitor apprehension of museum exhibitions are central to their success. Although there possibly as numerous ways of exploring museum exhibitions as there are visitors, modes of visitor apprehension (Lord, 2001) may generally be classified under four headings as follows: - contemplation

The mode of visitor apprehension, most preferred by art museums aiming at an aesthetic experience and it may also be utilized by history or science museum. It is stimulated by display of individual works of art, images, artefacts or specimens that are intended to be appreciated in and for themselves and perceived apart from the others around them. Conventionally, museum description labels used to provide us a little information as possible namely title, artist, dates, medium, donor that in order to ensure that contemplation of the object in and for itself. Now there is a mode in providing open-ended graphic commentaries on the galleries walls to stimulate thoughtful contemplation of works art and audio tours may also help some visitors to contemplate visitors aspects of the works on display. Contrast or comparison of work on exhibit may also engage in recreation a function, but even in those instances each individual work is intended to be appreciated on its own, as the basis for comparison. In this mode, the visitor remain relatively inactive physically although their intellect and emotions may very actively engaged. The transformative experience consists in the enhanced appreciation of the meaning and qualities of each individual work in and for itself.

\section{- comprehension}

History and natural science museums are more likely to feature contextual or thematic exhibition where the artefacts, specimens or other objects on display are not intended to be studied as individual objects, but to be associated to each other. They may be in a room setting or diorama, or they may simply be grouped in thematic or contextual relationships within a display case. Graphic may multi-layered, may combine words and images to aid comprehension. The purpose here is to encourage visitors to discover their meaning by relating one object to another, or each object to the overall context or theme. The visitor is more actively engaged in the process of making relationship, studying the graphics and labels as well as relating or comparing the objects to one another. The transformative experience consists in the quality impact discovery of the meaning of objects in their context or in relation to the exhibition theme.

- discovery 
The visitors can explores a range of specimens or artefacts, appreciating individual examples or noting relationships between them. Traditionally, this model has found in many natural history museums with systematic specimen collections, but now increasingly to be seen in all types of museums that have adapted visible storage means of exhibits, in which object are categorized as in storage but made visually accessible in glazed cases or drawers. Discovery of the artefacts' or specimens meaning may be further enhanced by the provision of full catalogue entries on the computer screen or laminated cards adjacent to the visible storage cases and cabinets.

\section{- interaction}

The most kinesthetically involving mode of visitor apprehension is the one favoured by many science centres and children museums, in which staff, volunteers, exhibitions apparatus, or duplicate specimens identified as hands-on education collection may be used to elicit a visitor respond that triggers the transformative visitor experience, the discovery of meaning that affects the visitors values, interests or attitudes. The person-to-person interaction can be among the most effective experience that the museums can offer. Many examples of interactive exhibits are mechanical or electronic devices such as lifting a panel cover to read and answer questions posed by graphics, or push a button to light up the three-dimensional model or map. Nowadays, interactive exhibition have included rides, simulation and virtual reality experience.

\subsection{Museum Learning, Communication of Meaning and the Shaping of Knowledge}

Museum actives in the shaping of knowledge because it was established over centuries ago. Its actively re-organizing their space and collections especially to the communication of meaning through the exhibition displays sequentially to present themselves as environment for formal learning, self-directed learning and informal learning based on experience frequently to new audiences.

\subsubsection{Defining Learning}

Hooper-Greenhill \& Moussouri (2002); Dawson (2006) perceives learning is a process of active engagement with experience. It is what people do when they want to make sense of the world around them. It may involve enhancing in skills, knowledge, understanding, values, feelings, attitudes and capacity to reflect (Hooper-Greenhill, 2007). Effective learning leads to change, development and the desire to learn more.

Learning is a dynamic process in which the learner uses sensory input and constructs meaning out of it. People be trained to learn as they learn to see as learning consists both of constructing meaning and constructing systems of meaning. The crucial action of constructing meaning is mental where it happens in the mind. Motivation is a key component in learning (Hein 1991:90-91).

\subsection{Methodology}


The methodology of this research is based on a triangulation method. This paper only uses qualitative methods, which refer the literature review in the purpose the identification of issues from the perspective views of museum scholars and experts toward creating direction in developing museum exhibitions in Malaysia for public learning. Majority of literature review is based on western scholar in knowing the scenario of museum learning within adult visitors. It is required for further enhance and the robustness of this research. This will be the foundation idea towards a study on visitor studies in Malaysia because there is a limited study on museum exhibition design within the scope of research on communication of meaning to the shaping of knowledge.

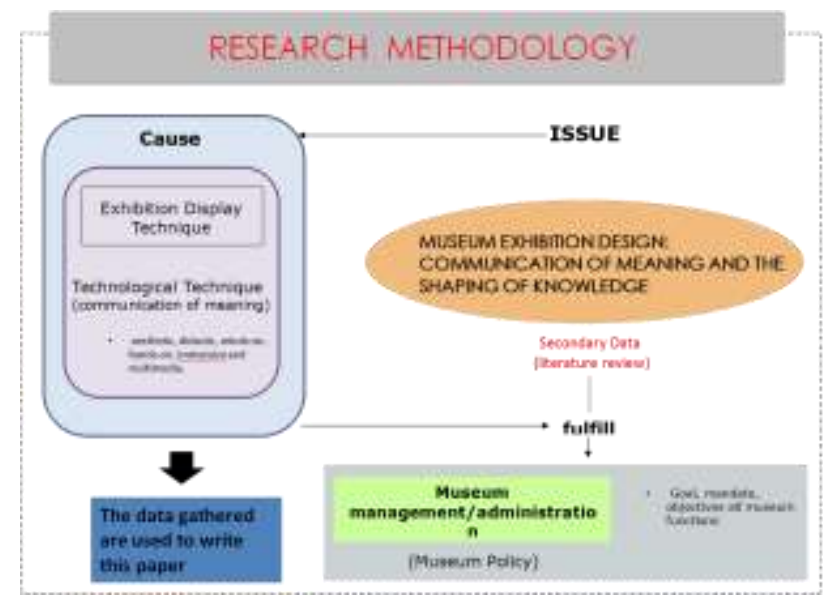

Fig. 1. Illustration of the flow diagram screening on literature review as a secondary data for research and identifies a relationship of communication of meaning in the shaping knowledge.

\subsection{Research Limitations}

Covering to parameters set by scholarship and research grant, where funds are only for local site activities (secondary data gatherings) within Malaysia. Any information and data regarding other countries within the enlighten on this paper is totally dependent by relative on the secondary data.

\subsection{Findings}

Research findings will be discussed in two phases. Phase one discuss on an identified museum learning and the type of learner involved. Also on phase two will intricate museum communication of meaning which elaborated display techniques in museum exhibitions. Finally, the phase two will discuss and conclude that the communication of meaning to reinforce about shaping of knowledge among the visitors of the museum. 


\subsection{Findings of Museum Learning and Learner}

As exhibition galleries develop closer relationships with their visitors, perhaps through recognizing their need in learning to be more accountable or through the desire to attract the wider range of people by the ways of communication of meaning via display techniques. Dawson (2006) has emphasized that, within the museum environment, the learner needs to be an active participant in the learning process and not as a passive recipient. Learners construct their own understanding of the world by reflecting on their experiences and interpreting what they see, hear and feel to the objects in what exhibition displays are offered. Learning are divided into three categories:

- Formal Learning: School type experience, teacher or staff led, might involve worksheets, often passive and may involve assessment

- Self-Directed Learning: Led by the learner when they are interested in a subject or motivated by a specific need (e.g. school project, vocational interest).

- Informal Learning: Unplanned casual encounters that lead to new insights, ideas or conversation.

Howard Gardner developed a theory on the dissimilar ways that individuals learn and process information, which called the "multiple intelligences theory". According to Gardner's theory, visitors might show well-built learning skills in any of seven different style categories that summarized in the following tables:

Table 1. Summaries Howard Gardner Theory of Learning that called 'Multiple Intelligence Theory' in the learning process to perceive information.

Howard Gardner Theory of Learning, 1983

\begin{tabular}{|c|c|c|}
\hline Types of Learner & Behavior of Learner & Communication of Meaning \\
\hline $\begin{array}{l}\text { 1. Visual Learner/Spatial Learner } \\
\text { Artists, photographers and architects } \\
\text { often exhibit this learning style. }\end{array}$ & $\begin{array}{l}\text { Enjoys by looking at pictures, } \\
\text { watching movies, drawing, } \\
\text { designing and creating three } \\
\text { dimensional representations. } \\
\text { Activities that appeal to the } \\
\text { spatial learning style include } \\
\text { sketching, graphing, creating } \\
\text { charts and mapping out } \\
\text { stories. }\end{array}$ & $\begin{array}{l}\text { Learns best by visualizing, } \\
\text { dreaming, working with colors } \\
\text { and pictures. }\end{array}$ \\
\hline 2. The Linguistic Learning & $\begin{array}{l}\text { Enjoys with reading, writing } \\
\text { and telling stories, debating, } \\
\text { reading aloud, drama and } \\
\text { creative writing. }\end{array}$ & $\begin{array}{l}\text { Learns best by saying, hearing } \\
\text { and } \\
\text { seeing words }\end{array}$ \\
\hline 3. The Logical/Mathematical Learner & $\begin{array}{l}\text { Enjoys doing experiments, } \\
\text { asking } \\
\text { questions, exploring patters } \\
\text { and } \\
\text { relationships }\end{array}$ & $\begin{array}{l}\text { Learns best by classifying, } \\
\text { working } \\
\text { with abstract patterns, } \\
\text { categorizing. }\end{array}$ \\
\hline
\end{tabular}


Ahmad, S., et.al. / Asian Journal of Environment-Behaviour Studies (ajE-Bs), 3(10) Sep / Oct 2018 (p.178-186)

\begin{tabular}{lll}
\hline 4. The Musical Learner & $\begin{array}{l}\text { Enjoys singing and humming, } \\
\text { listening to music, playing } \\
\text { instruments. }\end{array}$ & $\begin{array}{l}\text { Learns best by rhythm, } \\
\text { melody, } \\
\text { music. }\end{array}$ \\
\hline 5. The Kinetic Learner & $\begin{array}{l}\text { Enjoys moving around, } \\
\text { touching and talking. }\end{array}$ & $\begin{array}{l}\text { Learns best by touching and } \\
\text { moving, processing knowledge } \\
\text { through action. }\end{array}$ \\
\hline 6. The Social Learner & $\begin{array}{ll}\text { Enjoys being with friends, } \\
\text { talking to people and being } \\
\text { part of a group }\end{array}$ & $\begin{array}{l}\text { Learns best by sharing, } \\
\text { cooperating, interviewing and } \\
\text { comparing. }\end{array}$ \\
\hline $\begin{array}{l}\text { 7. The Solitary Learner/Introspective } \\
\text { Learner }\end{array}$ & $\begin{array}{l}\text { Enjoys working alone, } \\
\text { pursuing their own interests }\end{array}$ & $\begin{array}{l}\text { Learns best by self paced } \\
\text { instruction, reflecting and } \\
\text { individual projects. }\end{array}$ \\
\hline
\end{tabular}

Source: Dawson, M. (2006), Lord Academy, Museum Seminar, Malaysia National Museum, Kuala Lumpur; http://www.ehow.com/about_5367145_howard-gardner-learning-style.htm\#ixzz2ic/21m6R

\subsection{Findings for Museum Communication of Meaning (Exhibition Display Technique)} Brown (2001) has claimed that whether a museum is organizing its permanent collection displays, temporary exhibition or combination of both, the visitors experience of this exhibition will be enhanced if they are supported by a range of educational and other public programs or activities that reinforce communication of the exhibitions' core messages. This research has established that the communication of meaning in the ways by providing a choice of media and techniques led to an appeal in the direction of preferred learning styles with the level of interest and intellectual capacity to satisfy the agenda of the museum is summarize as follows:

Table 2. Summaries type of communication of meaning devices of exhibition techniques is identified in museum learning. Type of Communication of Meaning.

Type of Exhibition Technique Mode of Visitor Apprehension Type of Learner

\begin{tabular}{lll}
\hline 1. Aesthetic & Contemplative and reflective & $\begin{array}{l}\text { Appeals to visual and solitary } \\
\text { learners }\end{array}$ \\
\hline 2. Didactic & Text based, cases, murals & $\begin{array}{l}\text { Appeals to solitary and linguistic } \\
\text { learners }\end{array}$ \\
\hline 3. Hands - On & $\begin{array}{l}\text { Low technologies interactive } \\
\text { activities }\end{array}$ & $\begin{array}{l}\text { Appeals to mathematical / } \\
\text { logical learners, kinetic learners, } \\
\text { musical learners, social learners }\end{array}$ \\
\hline 4. Multimedia & $\begin{array}{l}\text { Videos, computer based, audio } \\
\text { and projection }\end{array}$ & $\begin{array}{l}\text { Appeals to visual and kinetic } \\
\text { learners }\end{array}$ \\
\hline
\end{tabular}




\begin{tabular}{lll}
\hline 5. Minds - On & $\begin{array}{l}\text { Encourages problem solving } \\
\text { and discussion plus exhibits that } \\
\text { ask question }\end{array}$ & $\begin{array}{l}\text { Appeals to social learners, } \\
\text { mathematical/logical learners }\end{array}$ \\
& $\begin{array}{ll}\text { Reconstructions that allow } \\
\text { visitors to become part of the } \\
\text { exhibition plus give context to } \\
\text { content and artifacts }\end{array}$ & $\begin{array}{l}\text { Appeals to all learners, } \\
\text { especially those who are kinetic } \\
\text { and social learners }\end{array}$ \\
&
\end{tabular}

Source:Dawson, M. (2006), Lord Academy, Museum Seminar, Malaysia National Museum, Kuala Lumpur.

\subsection{Discussion}

The findings of this study undertaken in qualitative research design have been discussed under findings related to visitors learning by communicate to the objects in the museum. Findings also related how visitor communicate to exhibition display related to their learning outcomes that the benefit to future research and future exhibition making. Keeping in mind that exhibition are only one form of expression in the spectrum of possible museum programs helps to open fresh up fresh ideas as to what might be the most effective communication tools for particular subject matter in any given situation. The museum is then in a position to make a decision about which techniques and approaches are been utilized with respect to specific communication goals.

One thing that is clear once the people using objects, the environment around them are tools in satisfying their instinctual impulse to expose, enlighten and interpret aspects of experience. These "environment of communicate" can be seen as precursors of a typology of human experience that recognized as exhibition design.

Exciting applications through new communication technologies are an opportunity for the museum to send virtual exhibitions where visitors can explore the museum's website, on the screen through images online. A few institutions are leading the way with the development of interactive with which visitors will be able to interact with the exhibition and also with each other (Lord, B \& Lord, G. Dexter, Gosling, K., 2001).

As such applications are developed, the visitors will be able to decide from the selection of a different way into the subject, to see the exhibits put into a variety of context and to access the modes of exhibition apprehension of possible interpretations.

\subsection{Conclusion}

The research indicates that museum education program design with different communication of meaning (educational methods) will provide cognitive learning and more awareness to visitors with various perspectives or outcomes. An examine was done at other contemporary means of communication that helps to explain what is unique about the museum exhibition as their medium of communication is affecting the majority of our emotional and exciting experience. Mayrand (2001), has claimed that to accomplish a good exhibition, it requires a global vision defining how visitor interact with the collection, knowledge or storyline must be 
developed. Only through the clear communication approach and a strong visitor experience strategy can deliver worthwhile exhibitions. Making continuous research regarding visitor studies will be produced the learning outcome to develop an idea that will carry out the interface in the shaping of knowledge for lifelong learning.

\section{References}

Hooper-Greenhill, E., (2007), Museum and Education, Routledge, New York, Pg: 34-35.

Hooper-Greenhill, E., (2000), Museum and the Interpretation of Visual Culture, Routledge, New York, Pg: 1-4.

Hooper-Greenhill , E ., (1992), Museum and the Shaping of Knowledge, Routledge, New York, Pg: 1-22.

Ismail (2011), Department of Museum and Antiquities Malaysia, (2011), The National Museum of Malaysia Kuala Lumpur: A Guide to the Gallery, the National Museum of Malaysia.

Jarrier, E. \& Bourgeon-Renault, D., (2012), Impact of Median Devices on the Museum Visit Experience and on Visitors Behavioral Intentions, International Journal of Arts Management, Pg: 18-21.

Lord,B \& Lord, G. Dexter, (2001), The Manual of Museum Exhibitions, Altamira Press, Pg: 12-26.

Lord, B \& Lord, G. Dexter, Mayrand, Y., (2001), The Manual of Museum Exhibitions: The Roles of Exhibition Designer, Altamira Press, Pg: 405-406.

Marstine, J. (2006), New Museum Theory and Practice, Blackwell Publishing, Australia. Macdonald, S., (2011), A Companion to Museum Studies, Wiley-Blackwell.

Unal, F., (2012), Observation of Object Preferences of Interest by Children Aged between 4 \& 8 in Museums: Antalya Museum Examples, Procedia Social and Behavioral Sciences 51(2012), Pg:362-367.

Moussouri, T., (2002), A Context for the Development of Learning Outcomes in Museums, Libraries and Archives, Research Centre for Museums and Galleries, University of Leicester, Pg:17-18.

Ormrod, J.E., (2012), Human Learning - Sixth Edition, Pearson, Pg: 1-4. 